\title{
Community Empowerment and Farmer Poverty Reduction in Developing Countries
}

\author{
Budi Permadi ${ }^{\text {a }}$ * \\ ${ }^{a}$ The Ministry of Agriculture, Indonesia
}

\section{INFORMASI ARTIKEL}

\section{Article history:}

Data submission : 10 September 2018

$1^{\text {st }}$ revision: 09 Januari 2019

Accepted: 16 April 2019

Available online: 02 Mei 2019

Keywords: community empowerment, farmer poverty reduction, Ghana, Indonesia

\begin{abstract}
Farmer community empowerment in agriculture development plays a significant role. Community empowerment is expected to reduce poverty, especially among farmers. The purpose of this paper is to summarize what are the causes of farmer poverty and what efforts have been made regarding community empowerment, to alleviate the poverty in the developing countries, especially in Indonesia and Ghana. This study used literature review approach to conduct a brief review of community empowerment and farmer poverty reduction. The results obtained, based on literature reviews and analyses, are the causes of farmer poverty such as low investment ability of farmers, dependence of farmers, dependence on funds, non-fulfillment of basic needs of farmer households, inadequate access to finance and extension services, etc. The findings suggest the programs to alleviate farmer poverty such as market creation for farmers, establishing or activating the Farmers Group, farmers group assistance, a program to procure demonstration field in each village, training, counseling, network formation, and providing loan.
\end{abstract}

2018 FIA UB. All rights reserved.

\section{Introduction}

Farmer community empowerment in agriculture development is important. The government, espescially the local governmnet which has direct contact to farmer community is responsible to empowering this community. Local government which has wide agriculture area responsibility and most of its population have livelihood in agriculture sector should conduct various efforts in empowering farmer community (Noventi, 2017).

Community empowerment broadly refers to the process of enabling communities to have a greater influence on the way that services are delivered in their local area. Community empowerment could also potentially have a significant impact on the well-being of communities. "Community empowerment" is the term that found favour with the 1997-2010 UK Labour government and which effectively describes participative approaches to local decision making (Adamson and Bromiley, 2013). This generally involves a twin approach of empowerment, referring to community empowerment which is "the giving of confidence, skills, and power to communities to shape and influence what public bodies do for or with them", and community engagement, which is "the process whereby public bodies reach out to communities to create empowerment opportunities" (CLG, 2007, p. 12).

The focus on community empowerment has led to policies that emphasise the role of the voluntary and community sector to "deliver" social policy through the neighbourhood agenda, developing the already complex relationship between the state and civil society (Adamson, 2006).

Community empowerment is expected to reduce poverty, especially among farmers. As stated by Oyekale (2011), the empowerment of youths-for example - through agricultural development programmes will reduce poverty and provide them with opportunities that will enable them to be gainfully employed. Some of the causes of poverty that commonly occur among farmers, are discussed below.

* Corresponding author. Tel.: +62-82213677940; e-mail: azam.budi@gmail.com 
In this paper I try to identify what are the causes of farmer poverty and what efforts have been made regarding community empowerment, to alleviate the poverty in the developing countries, especially in Indonesia and Ghana.

\section{Research method}

The design of this study used literature review approach. In this study, the researcher used secondary data from scientific journals and other documents such as books about community empowerment and farmers poverty reduction that were collected from the internet. Content analysis technique is used to analyze the data.

\section{Results and discussion}

The findings highlighted several issues about the causes of farmers poverty and the efforts to overcome it. In Indonesia, according to the research of Satriawan and Oktavianti (2012) farmers poverty resulted from several causes, including:

\subsection{Low investment ability of farmers}

There are several causes for the problem of the low ability of farmers to invest, including: limited mastery of agricultural technology, low agricultural knowledge and skills, imperfect information, and low access to agricultural production factors.

The agricultural production process relies heavily on weather conditions, land area owned, and dependence on chemical fertilizers and various kinds of pesticides and fungicides to eradicate pests. The use of fertilizers and pesticides is also done by "trial and error" without going through the laboratory research process or the like. If the weather does not support, many vegetable, fruit, rice, corn, flower and tobacco farmers experience crop failure.

The low education of farmers has a large contribution in problem of mastering knowledge, skills and technology. Education of farmers between not graduating from elementary school until graduating from junior high school, and on average farmers receive elementary education. The low level of their education is caused by the views of the people who do not place education as their top priority. Because of their low education awareness, access to mastering technology and skills is very difficult.

In addition, information relating to prices, markets, technology, climate, and so on, is very little owned by farmers. The weak information network owned by farmers for what crops are being produced in other regions also causes losses to farmers. This is because agricultural goods will be abundant if the vegetables they plant are the same. So that the price of agricultural goods will decrease. Such conditions of imperfect information also lead to low access to production inputs to farmers which in turn will lead to low investment capabilities of farmers.

Regarding access to low agricultural production factors, the average land ownership of farmers is less than 1 hectare and only partially even small people who own 1-1.75 hectares of land and there are even some farmers who do not have their own land and decide to rent or use land from PT. Perhutanan Indonesia (Perhutani) with intercropping planting system. The narrowness of land owned by farmers causes agricultural production to be small, and often cannot meet the needs of middlemen or collectors. If this happens, the farmer cannot buy the plant and must sell it to the market or wait for a small buyer who wants the plant. If the cost of accommodation for harvest and transportation is considered burdensome and not balanced with the sale price, farmers will act not to sell their crops and will use them for their animal feed.

A worse fate befell farmers who do not have private land. Those who do not have land usually become farm laborers or some who work on land owned by PT. Perhutani. The farmers have an agreement with Perhutani to plant trees determined by Perhutani. In return, Perhutani gave twenty logs of one hundred timber harvested and allowed farmers to utilize planted with trees with intercropping systems. Thus, farmers who only rely on the land will not get much results, because their job is not to be able to utilize the existing land to the full. The farmers also do not have their own land or leased land and loan land from Perhutani, they will become farm laborers, whose average income is Rp. 7,000 to Rp. 12,000 per half-day work (between 8 a.m. and 12 p.m.).

\subsection{Dependence of farmers}

The problems that cause farmers dependence include: low entrepreneurial spirit, inadequate capital availability, moral hazard, and weak agricultural institutional support. Indeed, to develop agriculture, it needs mobilization of rural people. Mobilization of rural people themselves requires the existence of a supportive economic structure, such as agricultural infrastructure, investment and transportation facilities and infrastructure (Gulo, et al. 2005 in Satriawan and Oktavianti, 2012).

The government has provided institutional facilities by forming farmer groups in each village, but in fact many farmer groups do not function, even poor membership. Rarely encountered active farmer groups. Cooperative and entrepreneurial functions do not appear in existing farmer groups. The general activities of farmer groups, on average, are only people gathering. This happened due to the presence of moral hazard and the weakness of agricultural institutional support. The poor management system of farmer group organizations also exacerbates the conditions of farmer groups.

Farmer dependency is a big problem that needs serious treatment and solution. Farmer is a main subject and actor in the field of agriculture. Without farmer, agriculture development has no meaning. Therefore, agriculture development in Indonesia should more focus on farmer community empowerment with the result that the farmer could be more creative, independent, and competitive. Empowering farmer community is the most important thing that will increase the capacity and capability of farmer community as the main actor in development of agriculture sector. By increasing their capacity and capability, the farmers can manage their 
farm land properly and increase the agriculture production that automatically also increase social welfare of the farmer. (Noventi, 2017). Therefore, community empowerment is expected to reduce farmers poverty.

\subsection{Dependence on funds}

Dependence of funds is experienced both by farmers and by the agricultural service as a driver of agricultural progress and the welfare of farmers. The condition of farmers who are poor in capital and the low skill of entrepreneurs makes the state of passive farmers and only pays capital loans from the Village Unit Cooperative (KUD) or bank and non-bank financial institutions. The limited capital owned by farmers has an impact on poverty suffered by farmers. Capital is needed when someone is engaged in agriculture. They need capital for various farming process needs, starting from labor costs, fertilizer and pesticide needs (fields of 0.25 ha require IDR 1 million for one planting), seed requirements, transportation costs, and others. So that, in the early planting period until the harvest period, farmers need substantial capital - but they cannot predict the results they will get. Therefore, farmers will decide to borrow money from the bank if they are able or in debt to the head of the farmer group or to someone they can lend. The bank's credit system is indeed considered very burdensome to farmers, because the interest is quite high, which reaches 2 percent more. While the loan system to the head of the Farmers Group is built on the basis of the trust and assets of the borrowing farmers. Lack of capital makes farmers unable to carry out agricultural production processes. If the farmers force them to keep producing, then they must try to procure production costs. Therefore, most farmers go with debt. They can submit debt to the bank, to the head of the Farmers Group or to individuals who are considered capable.

Meanwhile, the dependence of agricultural service funds is also very much on the budget allocation in carrying out its functions as a party responsible for the progress of the agricultural sector and the welfare of farmers will impact on less than optimal performance. So, the program output produced is not optimal. This will greatly affect the fate of farmers as an object that is strongly associated with the agricultural service.

\subsection{Non-fulfillment of basic needs of farmer households.}

If farmers are asked about fulfilling their daily basic needs, they firmly answer "enough". But what needs to be examined is whether "enough" means no debt or means that there are other sources of income to meet these basic needs. The findings in the field show that farmers can fulfill all their basic needs from other sources of income (alternative income). This is because the agricultural sector is uncertain. Uncertain conditions - price, market, harvest, etc. - so that these conditions make farmers' income from the agricultural sector very low.

In Ghana, according to the research of Abbeam and Baiyegunhi (2018) the poverty challenges are inadequate access to finance and extension services, poor infrastructural development, high incidence of pests and diseases, low fertility of the soil and low adoption of improved technology practices. Low adoption rates have the potential to hamper farm. productivity and subsequently shrink welfare gains from farm households. Previous studies have indicated that high incidence of pests and diseases could reduce farm output in the range of $60-90 \%$. High incidence of pests and diseases can affect farmers' ability to increase production and consequently impact on their welfare through income reduction. The most damaging cocoa pod disease in Ghana is 'black pod' caused by a fungus called Phythophtora megakarya and has the potential to reduce output by $40-90 \%$. Cocoa capsids or mirids (Distanthiella theobromae or salbegella singularis) are insect pests considered to be of severe constraint to cocoa production in West Africa, particularly in Ghana. Outbreaks of these pests can cause up to $75 \%$ decline in cocoa output.

To overcome the farmer poverty, priority programs that have been successfully compiled as solutions to various farmers' poverty problems based on community empowerment in Indonesia as found by Satriawan and Oktavianti (2012) are as follows:

First, the market creation program for farmers, this program can be implemented through the policy of purchasing agricultural products by the government and creating high skills for farmers to create high quality products.

Second, the program for establishing or activating the Farmers Group. The program began with the holding of entrepreneurship training and the internalization of the functions of cooperatives in farmers group institutions. This second program also requires the role and support of the government in the form of: agricultural extension tailored to the conditions of agricultural inputs of each region, provision of facilities for the formation/activation of farmers group, provision of supporting facilities for agricultural technology as well as budget allocations as facilities and budget allocation of funds as a driver of active farmer groups. As stated by Simmons and Birchall (2008), the role and potential of co-operatives have recently started to come to the fore again in discussions about poverty reduction.

Third, farmers group assistance program. This third program can be translated into several activities such as training in organizational management, networking, and the provision of companion human resources in each village because of the procurement of the program.

And finally, a program to procure demonstration field in each village. The application of this program is the availability of demonstration field facilities in each village as well as the provision of human resources for demonstration field supervisors in each village.

Other efforts in farmers community empowerment classified by Noventi (2017) into five kinds of activities namely training, counseling, network formation, providing loan, and socialization. Those kinds of activities are appropriate with the concept of community empowerment. However, there are activities of giving grants and subsidies that challenge the community 
empowerment concept which increases the local government expenditure.

Hermanto (2018) proposed human resource development and rural business strengthening and adoption of technology and innovation in agricultural businesses as the efforts to farmers poverty reduction. Human resource development in rural areas can be pursued in various ways, especially in developing the quality of poor human resources in rural areas from the aspect of education. Education can be carried out with a formal, informal, or informal approach. (Sumarno, 2011 in Hermanto, 2018).

Farmer Field School (Sekolah Lapangan Petani/SLP), is one approach to informal education in order to implement agricultural development programs with the community. SLP provides the widest opportunity for participants to interact with other participants, exchange experiences, express opinions, analyze each problem faced, draw conclusions and then dare to take action in order to solve common problems (Sutoyo, 2012 in Hermanto, 2018).

In addition to the problem of relatively low-quality human resources, rural economic development in general, and poverty alleviation in rural areas in particular face problems related to the small scale of household businesses. In view of the weak economic performance of the rural poor, the Government needs to implement an action program in the context of strengthening rural businesses. In this case, the Government can do: (1) Facilitating the formation of community institutions at the village level based on aspects: social, productive and/or sectoral economy; (2) Facilitate training and assistance to community institutions; (3) Facilitation of the establishment of business institutions based on natural resources (SDA) and territorial potential; and (4) Facilitation of capacity building of business institutions in managing their organizations (Director General of Development and Empowerment of Rural Communities, Ministry of Villages, Development of Disadvantaged Regions, and Transmigration, 2015 in Hermanto, 2018).

Agricultural research and development should focus on increasing agricultural production in a sustainable manner, considering socio-economic and rural institutions. Cooperation with stakeholders and farmer institutions is necessary to ensure that research and development services, as well as technology transfer, can be carried out in an inclusive and responsive manner to the needs of farmers. In addition, farmers need an environment conducive to innovation, including good governance, stable macroeconomic conditions, fair and transparent laws and regulations, guaranteed land ownership rights, and risk management and adequate support for agricultural and rural infrastructure. Increasing market access and capital, including access to purchases of farmers' production by the Government can provide incentives for the process of adopting new technologies and agricultural innovations.

Meanwhile, in Ghana, the effort to reduce farmers poverty according to the research of Abbeam and Baiyegunhi (2018), based on the study of cocoa farmers is the adoption of cocoa pesticides (insecticides and fungicides). Although it cannot be said that the adoption of pesticides management practices in Ghana reduce farmer poverty directly, the adoption of pesticides management practices improves households' welfare. In this study, the potential impact of pesticides management practices was evaluated by considering farmers' adoption decision on insecticides only, fungicides only and the combination of both insecticides and fungicides.

The results indicated that the probability of adoption of different packages of pesticides was influenced by different farmer-specific characteristics, households' assets, plot-specific characteristics, institutional variables, and farmers' perception about the incidence of pests and diseases. These results can be used to target farm-level programmes oriented towards the use of pesticides to stimulate productivity, and subsequently get smallholder cocoa farmers out of the whips of poverty. For instance, the positive and significant effect of education on the adoption of all the combination options suggests that education could be a critical route for stimulating farm productivity growth through adoption. Another key lesson from the result of the study is the significant role of institutional variables such as access to extension services and agricultural credit, suggesting the need to strengthen the extension institutions and farm credit schemes to accelerate and support pesticides management practices.

In the process, while the poor and other stakeholders seem aware of the need to work together, the collaboration process seems riddled with imperfections (Croes, 2014). However, efforts must still be made to alleviate farmers poverty.

\section{Conclusion}

The findings conclude that there are several causes of farmer poverty including low investment ability of farmers, dependence of farmers, dependence on funds, non-fulfillment of basic needs of farmer households, inadequate access to finance and extension services, poor infrastructural development, high incidence of pests and diseases, low fertility of the soil and low adoption of improved technology practices.

To overcome the farmer poverty, priority programs that have been successfully compiled as solutions to various farmers poverty problems, based on community empowerment are the market creation program for farmers, the program for establishing or activating the Farmers Group, farmers group assistance program, a program to procure demonstration field in each village, training, counseling, network formation, providing loan, socialization, human resource development and rural business strengthening, adoption of technology and innovation in agricultural businesses, and the adoption of pesticides management practices.

\section{References}

Abeam, G. D., \& Baiyegunhi, L. J. S. (2018). Welfare impact of pesticides management practices 
among smallholder cocoa farmers in Ghana. Technology in Society, 54(1), 10-19.

Adamson, D. (2006), Community regeneration policy, the state and civil society, in Day, G., Dunkerley, D. and Thompson, A. (Eds), Civil Society in Wales, University of Wales Press, Cardiff.

Adamson, D., \& Bromiley, R. (2013). Community empowerment: learning from practice in community regeneration. International Journal of Public Sector Management, 26 (3), 190-202.

Ajani, E. N., Mgbenka, R. N., \& Onah, O. (2015). Empowerment of Youths in Rural Areas through Agricultural Development Programmes: Implications for Poverty Reduction in Nigeria. International Journal of Research in Agriculture and Forestry, 2 (2), 34-41.

CLG (2007), Action Plan for Community Empowerment, The Stationery Office, London.

Croes, R. (2014). Tourism and poverty reduction in Latin America: where does the region stand? Worldwide Hospitality and Tourism Themes, 6 (3), 293-300.

Hermanto (2017). Poverty Reduction in Rural Areas: Human Resouce Development, Business Strengthening and Agricultural Innovation. Forum Penelitian Agro Ekonomi, 35 (2), 139150.

Noventi, I. A. (2017). Farmer Community Empowerment in Indonesia. Jurnal Ilmiah Administrasi Publik, 3 (3), 242-248.

Satriawan, B. \& Oktavianti, H. (2012). Upaya Pengentasan Kemiskinan pada Petani Menggunakan Model Tindakan Kolektif Kelembagaan Pertanian. Jurnal Ekonomi Pembangunan, 13 (1), 96-112.

Simmons, R., \& Birchall, J. (2008). The role of cooperatives in poverty reduction: Network perspectives. The Journal of Socio-Economics, 37, 2131-2140. 